\title{
upaya pengembangan bahasa INDONEsia DI LINGKUNGAN PENDIDIKAN SEBAGAI UPAYA PEMBENTUKAN KARAKTER GENERASI ERA MILENIAL
}

\author{
ROMI ISNANDA', MIA SETIAWATI ${ }^{2}$ \\ Pendidikan Bahasa dan Sastra Indonesia \\ FakultasKeguruan dan IlmuPendidikan \\ Universitas Bung Hatta \\ isnanda.romi@yahoo.com', miasetia706@gmail.com²
}

Pertama Diterima: 19 Mei 2019

Bukti Akhir Diterima: 6 Juni 2019

\begin{abstract}
Abstrak
Artikel ini membahas permasalahan tentang upaya pengembangan bahasa Indonesia di lingkungan pendidikan sebagai pembentukan karaketer generasi era milenial. Pendidikan merupakan lembaga resmi yang berada di bawah naungan negara, sejatinya pendidikan merupakan hal yang sangat penting yang harus dimiliki setiap individu manusia. Dengan adanya pendidikan diharapkan mampu mencerdaskan anak bangsa. Hal ini terlihat dari kedudukan atau keberadaan pendidikan yang tertera dalam Undang-Undang No.2 tahun 2003.Dalam dunia pendidikan kemampuan yang harus dimiliki setiap individu ialah kemampuan berbahasa yang dapat membantu seseorang dengan mudah berkomunikasi dengan baik. Namun pada kenyataannya hal itu tidak berjalan dengan semestinya,terlihat pada ruang dunia pendidikan di era milenial yang masih kurang menerapkan penggunaan bahasa baku dan benar, sehingga bahasa Indonesia selalu diselewengkan oleh penuturannya.Hal ini menjadikan bahasa Indonesia terlihat kurang berwibawa dan tidak teratur. Oleh sebab itu, perlunya upaya untuk menjaga yaitu (1) tidak takut salah dalam pengucapan, (2) tidak malu dalam pengucapan dan kesalahan, (3) tidak cemas jika ada kesalahan, (4) hilangkan ketidak percaya diri.
\end{abstract}

Kata Kunci: Pendidikan, bahasa Indonesia, upaya pengembangan.

\begin{abstract}
This article discusses the challenges of developing Indonesian in the education environment as millennial generation character formation. Education is an official institution that is under the auspices of the state, in fact education is a very important thing that must be owned by every individual human being. Education is expected to be able to educate the nation's children. This can be seen from the position or education stated in Law No. 2 of 2003. In the world of education, the ability that must be fulfilled by everyone who needs abilities that can help anyone who easily communicates with the good. But when it did not work properly, it was seen in the world of education in the millennial era that it still lacked raw and correct language, so that Indonesian was always distorted by its narrative. This makes Indonesian language look less authoritative and irregular. Therefore, (1) is not afraid of misreading, (2) not afraid of pronunciation and mistakes, (3) not afraid of mistakes, (4) eliminating self-mistrust.
\end{abstract}

Keywords: Education, Indonesian, Development Efforts. 


\section{PENDAHULUAN}

Pendidikan merupakan lembaga resmi yang berada di bawah naungan negara, sejatinya pendidikan merupakan hal yang sangat penting yang harus dimiliki setiap individu manusia. Dengan adanya pendidikan diharapkan mampu mencerdaskan anak bangsa. Hal ini terlihat dari kedudukan atau keberadaan pendidikan yang tertera dalam Undang-Undang No.2 tahun 2003 tentang setiap warga negara mempunyai hak yang sama untuk memperoleh pendidikan yang bermutu dan ayat (5) setiap warga negara berhak mendapatkan kesempatan meningkatkan pendidikan sepanjang hayat. Dengan ketentuan dan sampai batas umur tertentu, dalam setiap sistem pendidikan nasional biasanya ada kewajiban belajar.

Pendidikan juga bukan hanya melakukan proses pembelajaran atau diajarkan,namun juga proses dimana manusia mampu memanusiakan anak manusia. Dengan pendidikan seseorang mampu mengembangkan potensi yang dimiliki sehingga apa yang diperoleh dalam dunia pendidikan dapat dimanfaatkan dengan sebaik-baiknya. Habullah (2011:1) menjelaskan bahwa pendidikan diartikan sebagai usaha yang dijalankan oleh seseorang atau kelompok orang lain agar menjadi dewasa atau mencapai tingkat hidup atau penghidupan yang lebih tinggi dalam arti mental.

Keberadaan pendidikan di tengah-tengah masyarakat saat ini sesungguhnya dapat dimanfaatkan dengan baik oleh kalangan akademisi dan masyarakat awam, sebab pada kenyataannya ilmu pengetahuan dengan mudah diakses melalui apapun, sehingga mampu menambah pengetahuanpengetahuan baru yang dapat dikembangkan, baik dalam lingkungan pendidikan formal atau non formal. Saat ini fasilitas dalam dunia pendidikan begitu lengkap,dari buku hingga materi yang diperlukan sudah tersedia sehingga memudahkan dalam proses pembelajaran. Namun, seperti yang terlihat saat ini banyak aktivis akademik,siswa bahkan mahasiswa tidak memanfaatkannya. Hal tersebut dapat dilihat dari kurangnya keinginan penikmat pendidikan untuk mengetahui hal apasaja yang ada bahkan terjadi di lingkungan pendidikan.

Jadi, Pendidikan pada dasarnya ialah suatu keharusan yang dimiliki setiap orang karena dengan pendidikan seseorang mampu menghadapi berbagai perkembangan dan kemajuan zaman yang datang menghampiri kehidupannya. Dengan pendidikan seseorang bisa membentuk dan menata pola hidup yang lebih baik sehingga kedudukan dan fungsi manusia mempunyai kedudukan yang lebih tinggi dibandingkan dengan mahkluk lainnya dapat tercermin. Oleh sebab itu, tidak ada alasan bagi manusia untuk tidak memperoleh pendidikan.

Salah satu bentuk perkembangan zaman yang datang pada saat ini di tengah-tengah kehidupan masyarakat Indonesai adalah munculnya isu era Revolusi Industri 4.0 yang menginginkan masyarakat dalam interaksi sosial berbasis digital, secara perlahan sudah mulai tampak keberadaannya. Melalui isu Revolusi Industri 4.0, akan melahirkan generasi yang dinamakan dengan generasi milenial. Generasi milenial mempunyai perkembangan yang mencolok dibandingkan dengan generasi sebelumnya. Darmo (2015: 21) menjelaskan hasil penelitian menyebutkan bahwa generasi milenial mempunyai karakter yang unik di bandingkan generasi sebelumnya. Hal tersebut terlihar dari perilaku manusi yang tidak bisa terlepas dari teknologi.

Adanya kemajuan zaman yang datang tentunya berdampak pada permasalahan hidup manusia. Salah satunya berdampak pada dunia pendidikan, yaitu kurikulum, perangkat pembelajaran, dan bahasa yang dijadikan komunikasi dalam proses belajar mengajar di lingkungan pendidikan. 
Komponen-komponen tersebut harus berjalan satu arah sehingga sama-sama mendukung tujuan pendidikan nasional. Contohnya bahasa, di samping digunakan sebagai media komunikasi dalam proses pembelajaran, bahasa juga dapat digunakan sebagai sarana pembentukan karakter manusia. Dengan bahasa akan dapat diketahui perilaku seseorang. Dengan bahasa seseorang bisa saling berbagi antara yang satu dengan yang lainnya.

Namun, pada kenyataannya saat ini perkembangan bahasa Indonesia semakin menurun, terutama di dunia pendidikan seharusnya menjadi masalah besar yang harus segera dituntaskan. Sehingga bahasa resmi tersebut tidak semakin dipandang buruk bahkan tidak lagi diselewengkan dan dianggap remeh. Dengan adanya pendidikan bahasa Indonesialah seharusnya bahasa yang setiap hari digunakan mampu menjadi bahasa yang baik dan benar pada saat digunakan untuk berkomunikasi.

Hal kecil yang dapat kita lakukan untuk meningkatkan pengembangan bahasa Indonesia saat ini salah satunya ketika kita melakukan diskusi dalam lingkungan formal maupun non formal sebaiknya menggunakan bahasa Indonesia yang baik dan benar, sehingga mampu meningkatkan kualitas berbahasa Indonesia. Hal ini sebaiknya harus sangat diperhatikan, sehingga dunia pendidikan tidak terlena dengan zaman yang semakin maju namun bahasa Indonesia semakin ditinggalkan. Dengan keadaan seperti ini membuat penulis tertarik menulis artikel dengan judul "Upaya Pengembangan Bahasa Indonesia dalam Dunia Pendidikan".

\section{HASIL PENELITIAN DAN PEMBAHASAN}

\section{HakikatPendidikan}

Menurut Arfani (dalam Sidiknas Undang-Undang No 20 Tahun 2003) Hakikat pendidikan itu sendiri lebih berorientasi kepada terbentuknya karakter (kepribadian/jatidiri) seseorang. Setiap tahapan pendidikan dievaluasi dan dipantau dengan saksamasehingga menjadi jelas apa yang menjadi potensi positif seseorang yang harus dikembangkan dan apa yang menjadi faktor negatif seseorang yang perlu disikapi. Akar dari karakter ada dalam cara berpikir dan cara merasa seseorang.

Menurut Arifin (2012:73) Pendidikan merupakan bagian dari kegiatan kehidupan bermasyarakat dan berbangsa. Oleh sebab itu kegiatan pendidikan merupakan perwujudan dari citacita bangsa. Dengan demikian kegiatan pendidikan nasional perlu diorganisasikan dan dikelola sedemikian rupa supaya pendidikan nasional sebagai suatu organisasi dapat menjadi sarana untuk mewujudkan cita-cita Nasional.Selainitu Ki Hajar Dewantara (1962:14) menjelaskan bahwa Pendidikan umumnya berarti daya upaya untuk memajukan bertumbuhnya budi pekerti (kekuatan batin, karakter), pikiran (intellect) dan tubuh anak dalam pengertian Taman Siswa tidak boleh dipisah-pisahkan bagian-bagian itu, agar kita dapat memajukan kesempurnaan hidup, yakni kehidupan dan penghidupan anak-anak yang kita didik selaras dengan dunianya.

Berdasarkan pendapat tersebut dapat disimpulkan bahwa pendidikan merupakan cara seseorang untuk mendidikdan mencerdaskan diri sendiri agar mencapai kemapuan yang dapat melatih kecerdasan fisik maupun jasmani yang terdapat dalam diri seseorang sehingga mampu 
diterapkan dalam kehidupannya. Sehingga dengan begitu kehidupan seseorang dapat dengan layak dijalani dan dinikmati dengan semestinya sesuai dengan dunia dan lingkungannya.

\section{Penikmat Pendidikan}

Dimensi-dimensi pendidikan mencakup pihak-pihak yang bersentuhan langsung dengan permasalahan pendidikan. Pihak-pihak yang dimaksud, yaitu dimulai dari penyelenggara pendidikan, pengamat pendidikan, pengguna pendidkan, pengamat pendidikan, dan penikmat pendidikan itu sendiri. Penikmat pendidikan berkaitan dengan orang yang langsung merasakan pendidikan. Dengan demikian, muncul pertanyaan yang berkaitan dengan penikmat pendidikan, "Apakah sudah seluruh masyarakat Indonesia merasakan duduk di bangku pendidikan? Jika demikian pertanyaannya, tentunya kita dapat membidik dan melirik orang-orang di sekeliling kita, apakah semuanya sudah merasakan pendidikan. Jawaban pertanyaan tersebut adalah belum semuanya masyarakat Indonesia merasakan pendidikan.

Menurut Nurkolis (2013:25) Pendidikan juga merupakan sebuah aktivitas yang memiliki maksud atau tujuan tertentu yang diarahkan untuk mengembangkan potensi yang dimiliki manusia baik sebagai manusia ataupun sebagai masyarakat dengan sepenuhnya.Sama halnya dengan kehidupan yang dapat dinikmati oleh seluruh lapisan manusia di muka bumi,maka pendidikan pun begitu. Pendidikan dapat dinikmati dan dirasakan oleh seluruh umat manusia, namun pada kenyataan yang ada masih banyak yang belum beruntung untuk mengenyam bangku pendidikan. Hal ini terlihat dari banyaknya manusia (generasi muda) yang masih belum duduk di bangku sekolah.

\section{Penyelenggara Pendidikan}

Pendidikan yang pada dasarnya ialah suatu usaha sadar dan terencana untuk menciptakan suasana belajar agar peserta didik secara aktif mengembangkan potensi dirinya untuk memiliki kekuatan spiritual keagamaan, pengendalian diri, kepribadian, kecerdasan, sikap sosial dan keterampilan yang diperlukan dirinya, masyarakat, bangsa dan negara Sisdiknas (dalam Jumali, dkk, 2004:166) menjelaskan bahwa sebuah tujuan yang saat ini masih tetap di usahakan untuk mampu mencapai tujuan yang benar-benar terwujud dengan sempurna.

Dunia pendidikan tidak akan lepas dari naungan negara yang mampu mengatur segala sesuatu permasalahan yang ada di dalamnya. Namun, fungsi dan penerapannya dalam hal ini perlu dibenahi. Dalam hal ini pembenahan serta penyempurnaan dunia pendidikan dapat berjalan dengan semestinya jika negara, pendidik dan pesrta didik mampu menjadikan dunia pendidikan menjadi hal yang wajib diperbaiki dan dinikmati dengan sebaik-baiknya.

\section{Permasalahan Pendidikan}

Menurut Lailiyah, Wulansari (2016:166) menyatakan dalam pengembangan ilmu pengetahuan dan teknologi pada dunia pendidikan harus ditunjang oleh kemampuan pemanfaatan, pengembangan, dan penguasaan ilmu terapan dan ilmu pengetahuan dasar secara seimbang. Namun pada kenyataan yang ada di lapangan masih banyak peserta didik dan aktivis pendidikan yang masih memiliki masalah dalam menempuh pendidikan. Hal ini terlihat masih banyak peserta didik yang mengasumsikan bahwa pendidikan adalah suatu hal yang sangat menyulitkan, terutama dalam 
proses belajar mengajar yang menjadi hal pokok dalam sebuah pendidikan serta bahasa menjadi salah satu alat komunikasi dalam pembelajaran.

Kenyataan yang ada di lapangan bahasa Indonesia tidak selalu digunakan dengan baik oleh setiap orang bahkan aktivis akademik. Hal ini terlihat masih kurangnya keinginan peserta didik menggunakan Bahasa Indonesia dengan baik dan benar sebagai sarana komunikasi. Ini jelas terlihat bahkan jelas dirasakan jika seseorang tersebut berkecimpung dalam dunia pendidikan, Bahasa Indonesia dirasakan bukan Bahasa gaul, merupakan Bahasa kaku yang menyulitkan seseorang dalam berkomunikasi. Padahal jika Bahasa Indonesia digunakan untuk berkomunikasi dengan baik dan benar lebih memudahkan setiap orang berkomunikasi bahkan dapat melestarikan Bahasa Indonesia itu sendiri.

Selanjutnya Lailiyah, Wulansari (2016:167) Salah satu usaha untuk meningkatkan penguasaan pengetahuan dasar adalah dengan meningkatkan keterampilan berbahasa.Secara umum mata pelajaran bahasa Indonesia bertujuan agar peserta didik memiliki kemampuan antara lain (1) menghargai dan bangga menggunakan bahasa Indonesia sebagai bahasa persatuan dan bahasa negara, (2) memahami bahasa Indonesia dari segi bentuk, makna, dan fungsi, serta menggunakannya dengan tepat dan kreatif untuk berbagai tujuan, keperluan, dan keadaan, (3) menggunakan bahasa Indonesia untuk meningkatkan kemampuan intelektual, serta kematangan emosional dan sosial, (4) berkomunikasi secara efektif dan efisien sesuai denga etika yang berlaku, baik secara lisan maupun tulis, (5) menikmati dan memanfaatkan karya sastra untuk memperluas wawasan, memperhalus budi pekerti, serta meningkatkan pengetahuan dan kemampuan berbahasa, (6) menghargai dan membanggakan sastra Indonesia sebagai khasanah budaya dan intelektual manusia Indonesia, Depdiknas (2006).

Namun yang dapat dilihat saat ini ialah tidak semua siswa bahkan aktivis akademik memiliki kemampuan tersebut. Hal ini terlihat sangat jelas ketika kita berkomunikasi dalam lingkungan pendidikan, Mereka menganggap bahwa Bahasa dalam dunia pendidikan tidaklah begitu penting.Contoh sederhana dapat kita lihat pada saat peserta didik berkomuniikasi di sekolah tidak menggunakan bahasa Indonesia yang baik dan benar,Namun bahkan semakin di selewengkan penggunaannya. Permasalahan seperti inilah yang seharusnya menjadi perhatian utama dalam pendidikan.

\section{Upaya Peningkatan Penggunaan Bahasa sebagai Pembentukan Karakter}

Menurut Lailiyah, Wulansari dalam Juhana (2012:167) terdapat empat faktor yang menyebabkan siswa mengalami kesulitan dalam mengembangkan keterampilan berbicara, yaitu (1) takut salah, artinya siswa takut melakukan kesalahan dalam mengungkapkan pendapat atau gagasan yang dimilikinya, (2) perasaan malu, artinya sifat emosional yang muncul saat siswa diminta untuk berbicara, (3) kecemasan, merupakan perasaan tegang, takut, dan gelisah yang muncul saat siswa diminta mengungkapkan pendapatnya, dan (4) kurang percaya diri, merupakan perasaan yang sering muncul ketika siswa mengungkapkan gagasannya dan ide tersebut kurang dipahami oleh teman-temannya.

Lailiyah, Wulansari dalam (Gudu 2015) menyatakan bahwa keterampilan berbicara dengan bahasa yang baik dan benar pada siswa tersebut dapat dikembangkan melalui tiga tahapan. Pertama, mengembangkan motivasi, artinya seorang siswa yang baik harus dapat mengembangkan motivasi 
pada dirinya sendiri untuk dapat mengembangkan keterampilan berbicaranya. Kedua, peran guru, merupakan tugas seorang guru untuk memilih metode yang tepat dan efektif dalam mengembangkan keterampilan berbicara pada siswanya. Berdasarkan pendapat dan penjelasan tersebut, maka perlu strategi belajar "baru" yang lebih memberdayakan siswa.

Di samping itu, ketika penggunaan bahasa Indonesia, baik lisan maupun tulisan sudah berada pada tataranp praktik yang tepat maka akan dapat membawa wibawah dan kedududkan seseorang sebagai warga negara yang berkarakter dapat terwujud. Selanjutnya, akan berdampak terhadap kedudukan dan fungsi bahasa Indonesia di tengah-tengah kehidupan masyarakat Indonesia. Bahasa Indonesia sebagai jati diri bangsa, bahasa Indonesia sebagai bagian dari budaya, dan bahasa Indonesia sebagai salah satu alternatif pembentukan karekter tidak dapat tewujud dengan baik.

Jika dilihat dari dua konsep yang telah dikemukakan tersebut terlihat jelas jika penggunaan bahasa Indonesia yang baik dan benar akan terlihat ketika seseorang yang berkecimpung di dunia pendidikan mampu menerapkan hal tersebut dalam berkomunikasi sehari-hari dan dapat dikembangkan. Sehingga setiap peserta didik mampu melatih komunikasi menggunakan bahasa yang baik dengan dibantu oleh peran pendidik yang mampu menggunakan metode dalam proses pembelajaran.

\section{PENUTUP}

Pendidikan merupakan suatu usaha yang dapat dilakukan oleh seseorang dengan tujuan tertentu berupa mengupayakan proses memanusiakan anak manusia. Sehingga usaha tersebut dapat berjalan sesuai dengan yang diharapkan agar memperoleh hasil yang seharusnya. Dengan adanya pendidikan segala sesuatu dapat dimanfaatkan dengan baik.Dalam hal ini, yaitu mengenai penggunaan bahasa Indonesia yang baik dan benar dalam berkomunikasi terutama dalam dunia pendidikan,baik formal maupun non formal.

Kemajuan penggunaan bahasa Indonesia yang baik dan benar dalam dunia pendidikan seharusnya diupayakan dengan baik, sehingga ketika melakukan komunikasi/diskusi siswa dan aktivis akademik akan lebih mudah melakukan komunikasi karena sudah adanya pemahaman mengenai pentingnya upaya pengembangan berbahasa Indonesia yang baik dan benar, Dalam hal ini terutama dunia pendidikan. Dengan adanya upaya yang dilakukan mampu menjadikan bahasa Indonesia kembali menjadi bahasa yang dipandang baik oleh penuturnya. Selain itu kita dapat melestarikan bahasa resmi negara yaitu bahasa Indonesia. Dengan demikian, pendidikan serta pengupayaan bahasa Indonesia di kalangan aktivis akademik dapat di tingkatkan dan mudah untuk diterapkan. Sehingga dalam dunia penidikan saat berkomunikasi akan dengan mudah menggunakan bahasa Indonesia yang baik dan benar. 


\section{DAFTAR PUSTAKA}

Al Arifin, A. H. (2012). Implementasi Pendidikan Multikulutral dalam Praksis Pendidikan di Indonesia. Jurnal Pembangunan Pendidikan: Fondasi dan Aplikasi, 1(1).

Arfani. (2016). Mengurai Hakikat Pendidikan, Belajar dan Pemelajaran. PPKN dan Hukum, 11, 8283.

Darmo, I. S. (2015). Millennials Green Culture: The Opportunity And Challenge (A Case Study Of Higher Education Student). International Multidiciplinary Conference on Social Sciences (IMCoSS), 1, 21.

Habullah. (2011). Dasar-dasar Ilmu Pendidikan. Jakarta: Rajawali Pers.

Lailiyah, N., \& Wulansari, W. (2017). Peningkatan Keterampilan Berbicara Melalui Metode Diskusi Kelompok Model Tanam Paksa Siswa Kelas X Pemasaran 1 SMK PGRI 2 Kediri. Jurnal Pendidikan (Teori dan Praktik), 1(2), 166-173.

Nasional, D. P. (2003). Sistem pendidikan nasional. Jakarta (ID): Depdiknas.

Nurkholis. (2013). Pendidikan Dalam Upaya Memajukan Teknologi. Jurnal Kependidikan, 1, 25. 